\title{
Predictions of El Niño, La Niña and Record Low Chicago Temperature by Sunspot Number
}

\author{
Tai-Jin Kim
}

Department of Chemical Engineering, University of Suwon, Hwasung-City, South Korea

Correspondence to: Tai-Jin Kim, tjkim@suwon.ac.kr

Keywords: Prediction, El Niño, La Niña, Record Low Chicago Temperature, Sunspot Number

Received: March 21, 2019 Accepted: June 27, 2019 Published: June 30, 2019

Copyright $\odot 2019$ by authors and Scientific Research Publishing Inc.

This work is licensed under the Creative Commons Attribution International License (CC BY 4.0).

http://creativecommons.org/licenses/by/4.0/

\section{(c) (1) Open Access}

\section{ABSTRACT}

The El Niño Index, defined as 4 intensities (very strong, strong, moderate, weak) in Oceanic Niño Index (ONI), was positively correlated with the average sunspot number at each intensity. The La Niña Index, defined as 3 intensities (strong, moderate, weak) in ONI, was negatively correlated with the average sunspot number from 1954 to 2017. It appears that very strong El Niño events occur frequently during the maximal sunspot number while strong La Niña events more often occur during the minimal sunspot number. Since greenhouse-gas is continuously increased, it is therefore proposed that the maximal sunspot number is a major parameter for prediction of El Niño while the minimal sunspot number applies in the same way for La Niña. El Nino/La Nina events can be classified as four typical cases depending upon the submarine volcanic activities at seamounts in Antarctica and South America. The Sea Surface Temperature (SST) of the South and Central Americas are warmer than SST of East Australian Current (EAC), due to the strong volcanic eruptions in the Seamounts and the Ridges in South and Central Americas. This results in the Central Pacific Current (CPC) flowing from east to west due to the second law of thermodynamics for thermal flow from hot source to cold sink. In contrast the opposite direction is made if SST in EAC is warmer than SST in the Central/South American Seamounts and Ridges, due to the strong volcanic eruptions in the Antarctic Seamounts and Ridges. Chicago was selected as a case study for the relationship between extreme cold weather conditions and minimal sunspot number. Previous attempts at predicting weather patterns in Chicago have largely failed. The years of the record low temperatures in Chicago were significantly correlated with the years of the minimal sunspot number from 1873 to 2019 . It is forecast that there may occur a weak La Niña in 2019 and another record low temperature in Chicago in January of 2020 due to the phase of the minimal sunspot number in 2019. It may be possible to predict very strong El Niño events with the year of maximal sunspot number as El Niño 
Index $\left(R^{2}=0.7363\right)$ and the years of strong volcanic eruption in the Galapagos Hot Spot (GHS) $\left(R^{2}=0.9939\right)$, respectively. An El Niño event is thus expected during the year of strong volcanic eruption in the GHS. Strong La Niña events can be expected during the year of minimal sunspot number with La Niña Index $\left(R^{2}=0.9922\right)$. Record low temperatures in Chicago can be also predicted $\left(R^{2}=0.9995\right)$ during the year of the minimal sunspot number, as was recently the case in January, 2019.

\section{INTRODUCTION}

The sunspot numbers between 1870 and 2020 are shown in Figure 1 [1] while the detailed sunspot number between 2000 and 2019 was shown in another work of Hataway [2]. Ultraviolet radiation increases dramatically during high sunspot activity. The converse is true during minimum sunspot activity [3]. Since 1880 AD, El Niño events have occurred roughly every 2 - 7 years with no clear periodicity [4] while the sunspot number (measured in Brussels of Belgium and Ottawa/British Columbia of Canada [5]) changes through an average cycle of 11 years with 14 months (1 year and 2 months) standard deviation. Maximal sunspot number causes the highest solar radiation upon the Earth to induce very strong El Niño events while the minimal sunspot number provides the lowest solar radiation upon the Earth to induce strong La Niña events, as well as the record low temperature in Chicago, as illustrated in Figure 1.

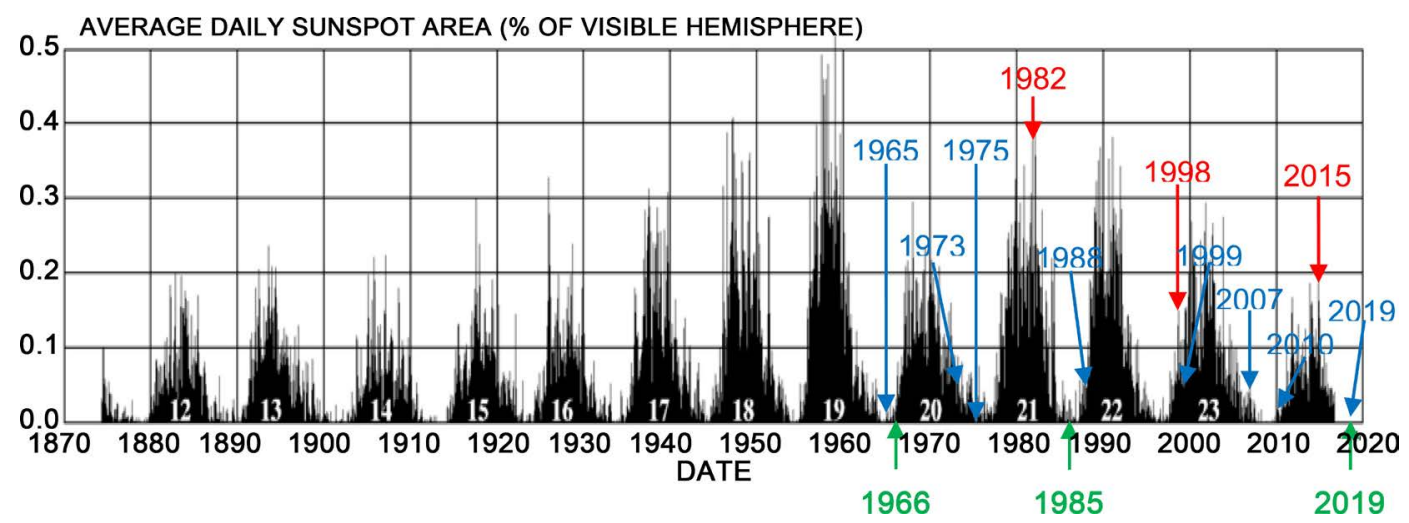

Figure 1. Sunspot numbers with representative years [1] of very strong El Niño events in red color and strong La Niña events in blue color with data in Table 5 while the years of the record low temperatures in Chicago were expressed in green color with data in Table 6.

Kim [5] proposed the minimal sunspot number for prediction of the avian influenza virus outbreak from 1878 to 2016 with high linearity $\left(R^{2}=0.9967\right)$.

Kim [6] also showed that there was a close relationship $\left(R^{2}=0.8539\right)$ between MERS-CoV in Eastern Mediterrane region and maximal sunspot number from 2012 to 2018.

The purpose of the present study is to predict important natural phenomena such as El Niño and La Niña events, and years of the record low Chicago temperature by the sunspot number.

\section{BACKGROUND}

\subsection{El Niño and La Niña Events}

Every two to seven years, an unusually warm pool of water-sometimes two to three degrees Celsius higher than normal-develops across the eastern tropical Pacific Ocean to create a natural short-term climate change event. This warm condition, known as El Niño, spurs extreme weather patterns around the world, from flooding in California to droughts in Australia [7]. It happens when Sea Surface Temperature 
(SST) in the Equatorial Pacific Ocean warm up and the increased ocean surface temperatures influence air and moisture movement around the globe [8]. El Niño is known as an irregularly occurring weather phenomenon created through an abnormality in wind and ocean circulation. While it originates in the Equatorial Pacific Ocean, El Niño has wide-reaching effects. In a global context, it affects rainfall, ocean productivity, atmospheric gases and winds across continents. At a local level, it influences water supplies, fishing industries and food sources [9].

El Niño/La Niña events apparently play a critical role in the variability of Southern Ocean SST. Higher SST anomalies were observed in El Niño years while cooler anomalies were seen during La Niña years. During El Niño years, the ocean becomes noticeably warmer and the air pressure is high with rainfall and flooding. La Niña is essentially the anti-El Niño. Instead of warm water and high air pressure, waters are cold and air pressure is low with drought and cold weather. La Niña years often cause heavy snowfalls even in parts of the world far away from the Pacific [10].

Gay-Lussac's law [11] is given by,

$$
\frac{P_{H}}{T_{H}}=\frac{P_{L}}{T_{L}}
$$

where

$P_{H}, P_{L}=$ Pressures at high (El Niño) and low (La Niña) in the tropical Pacific,

$T_{H}, T_{L}=$ Temperatures at high (El Niño) and low (La Niña).

An El Niño event causes flooding due to $T_{H}$ with high evaporated seawater while La Niña occurs due to $T_{L}$ with low evaporated seawater. Therefore, if $T_{H}$ of SST is satisfied, pressure becomes high $\left(P_{H}\right)$ so that the South Equatorial Current flows from the hot source of the east Pacific $\left(P_{H}, T_{H}\right)$ to the cold sink of the west Pacific $\left(P_{L}, T_{L}\right)$, according to the second law of thermodynamics.

\subsection{Oceanic Niño Index}

The Oceanic Niño Index (ONI) [12] is defined as the three-month running-mean SST departures from the average in the Niño 3.4 region (i.e., $5^{\circ} \mathrm{N}-5^{\circ} \mathrm{S}, 120^{\circ} \mathrm{W}-170^{\circ} \mathrm{W}$ ) in Figure 2, and is a principal measure for monitoring, assessing, and predicting El Niño-Southern Oscillation (ENSO). NOAA operational definitions for El Niño and La Niña are as follows:

El Niño: characterized by a positive ONI greater than or equal to $+0.5^{\circ} \mathrm{C}$.

La Niña: characterized by a negative ONI less than or equal to $-0.5^{\circ} \mathrm{C}$.

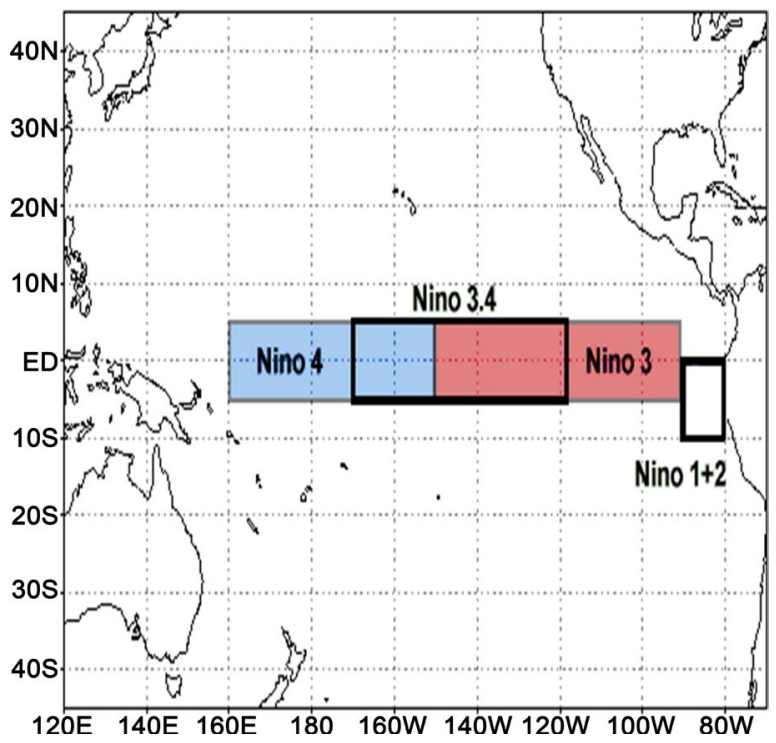

Figure 2. El Niño regions in the Pacific [13]. 
By historical standards, to be classified as a full-fledged El Niño or La Niña episode, these thresholds must be exceeded for a period of at least 5 consecutive overlapping 3-month seasons [13]. ONI has become the defacto standard that NOAA uses for identifying El Niño (warm) and La Niña (cool) events in the tropical Pacific.

El Niño regions in the Pacific were shown in Figure 2 and defined as [13]:

1) El Niño $(1+2) 0^{\circ}-10^{\circ} \mathrm{S}, 80^{\circ}-90^{\circ} \mathrm{W}$ east Pacific

2) El Niño (3) $5^{\circ} \mathrm{N}-5^{\circ} \mathrm{S}, 90^{\circ}-150^{\circ} \mathrm{W}$ central Pacific

3) El Niño (4) $5^{\circ} \mathrm{N}-5^{\circ} \mathrm{S}, 150^{\circ}-160^{\circ} \mathrm{W}$ west Pacific.

\subsection{Galapagos Hot Spot}

The Galapagos Islands are reported to be a "hot spot", which is a region of high thermic flux due to the presence of a magmatic plume ascending from the earth's mantle $(700-3000 \mathrm{~km})$ [14]. The hot energy side of the internal thermic magma after volcanic eruption in the GHS is transferred to the cold energy side of the undersea seamount of the Carnegie Ridge (CAR), which is a volcanic plateau formed during the eastward movement of the new Nazca Plate over the GHS [15]. The Galapagos archipelago, which is made up of 13 major volcanic islands, occupies a submerged platform, which rises more than 3 kilometers above the adjacent seafloor. Upwelling within the nutrient-laden Peru Current is responsible for the great biological productivity of the ocean off the coasts of Peru and Chile.

The trade winds blow from the normally high-pressure area over the eastern Pacific (near Central and South America) to the normally stable low-pressure area over the western Pacific (north of Australia). In the Southern Oscillation, winds across the tropical Pacific reverse direction and blow from west to east.

During El Niño events, the surface ocean around the Galapagos warms substantially and the islands receive significantly more rainfall than in normal years. The warmer water is less nutrient-enriched than the cool waters that normally surround the Galapagos and the marine ecosystem consequently becomes disrupted, resulting in a high mortality rate of coral, seabirds, and marine mammals during the strongest El Niño events, such as those in 1982-83 and 1997-98 [16].

\section{RESULTS}

\subsection{Volcanic Seamounts}

The planet's crust is broken into 17 major rigid tectonic plates while volcanoes and earthquakes are generally found in the plate boundaries at the bottom of the oceans. Therefore, most volcanic activity is submarine, as seen in deep sea hydrothermal $\left(\geq 350^{\circ} \mathrm{C}\right)$ black smokers vents of volcanic gases at the East Pacific Rise [17].

Volcanic gases are commonly composed in the order of $\mathrm{H}_{2} \mathrm{O}(37 \%-97.1 \%), \mathrm{CO}_{2}, \mathrm{SO}_{2}(0.50 \%-$ $11.8 \%), \mathrm{H}_{2}, \mathrm{CO}, \mathrm{H}_{2} \mathrm{~S}(0.04 \%-0.68 \%), \mathrm{HCl}, \mathrm{HF}$ [18]. Toxic chemicals $\left(\mathrm{SO}_{2}, \mathrm{H}_{2} \mathrm{~S}, \mathrm{HCl}, \mathrm{HF}_{2} \mathrm{H}_{2} \mathrm{SO}_{4}\right)$ from submarine volcanoes have reduced the fishery productivity.

Table 1 summarizes the Ridge and Basin of South and Central Americas.

\subsection{East Pacific and Central American Countries with Volcanoes}

Peru (Humboldt) Current with South Equatorial Current moves away from the sources of volcanoes in the Galapagos Islands, Peru, Chile, Panama, Honduras, Nicaragua, Costa Rica, Guatemala, Mexico, Colombia and Ecuador toward the sink of the west Pacific along trajectories of South Equatorial Current and Equatorial Winds in the equatorial Pacific.

Table 2 summarizes the East Pacific and Central American Countries with precipitation, area, heat source, volcano, earthquake, and Ridge.

It is evident that countries in the Equatorial Pacific Ocean located in mixing zones in the Panama Basin among warm (Panama $30^{\circ} \mathrm{C}$, South Equatorial $27^{\circ} \mathrm{C}$ ) and cold (Peruvian Coastal $16^{\circ} \mathrm{C} 21^{\circ} \mathrm{C}$, Peruvian Oceanic $9^{\circ} \mathrm{C} \sim 21^{\circ} \mathrm{C}$, Cromwell $13^{\circ} \mathrm{C}$ ) currents, showed extensive precipitations; Costa Rica (2926 mm), 
Table 1. Ridge and basin of South and Central Americas.

\begin{tabular}{|c|c|c|c|c|}
\hline Step & Name & Location & Length (km) & Plate/Country \\
\hline 1 & Chile Rise & $35-45^{\circ} \mathrm{S} / 76-104^{\circ} \mathrm{W}$ & 2250 & $\begin{array}{c}\text { Nazca Plate/Antarctic } \\
\text { Plate }\end{array}$ \\
\hline 2 & $\begin{array}{l}\text { Juan Fernández } \\
\text { Ridge }\end{array}$ & $33^{\circ} \mathrm{S} / 76-82^{\circ} \mathrm{W}$ & $\begin{array}{c}900 \\
\text { (3900 m depth) }\end{array}$ & $\begin{array}{l}\text { Volcanic islands and } 11 \\
\text { seamount chains on the } \\
\text { Nazca Plate }\end{array}$ \\
\hline 3 & Chile Basin & $30-32.5^{\circ} \mathrm{S} / 80-90^{\circ} \mathrm{W}$ & (4800 m depth) & Chile \\
\hline 4 & Iquique Ridge & $23-28^{\circ} \mathrm{S} / 73-79^{\circ} \mathrm{W}$ & 600 & Peru-Chile Trench \\
\hline 5 & Nazca Ridge & $14.5-22^{\circ} \mathrm{S} / 76.3-82^{\circ} \mathrm{W}$ & $\begin{array}{c}1000 \\
(200 \mathrm{~km} \text { wide })\end{array}$ & Peru Trench \\
\hline 6 & Peru Basin & $14^{\circ} \mathrm{S} / 83^{\circ} \mathrm{W}$ & (4000 m depth) & Nazca Plate/Peru \\
\hline 7 & $\begin{array}{c}\text { Ecuador Continental } \\
\text { Shelf }\end{array}$ & & (200 m depth) & Nazca Plate/Ecuador \\
\hline 8 & $\begin{array}{c}\text { Ecuador Insular } \\
\text { Shelf }\end{array}$ & & & Nazca Plate/Ecuador \\
\hline 9 & $\begin{array}{c}\text { Carnegie Ridge } \\
\text { (Galapagos Islands, } \\
13 \text { volcanoes) }\end{array}$ & $0-2^{\circ} \mathrm{S} / 81.3-85.0^{\circ} \mathrm{W}$ & $\begin{array}{c}1350 \\
(300 \mathrm{~km} \text { wide }) \\
(1000-3500 \mathrm{~m} \mathrm{depth})\end{array}$ & Ecuador \\
\hline 10 & Cocos-Nazca Ridge & $2-3^{\circ} \mathrm{N} / 94.6-96.5^{\circ} \mathrm{W}$ & (2000 m depth) & $\begin{array}{c}\text { Galapagos } \\
\text { (Cocos-Nazca) } \\
\text { Spreading Center }\end{array}$ \\
\hline 11 & Malpelo Ridge & $2-5^{\circ} \mathrm{N} / 80-81^{\circ} \mathrm{W}$ & $\begin{array}{c}300 \mathrm{~km} \\
(100 \mathrm{~km} \text { wide })\end{array}$ & Carnegie Ridge/Colombia \\
\hline 12 & Panama Basin & $5^{\circ} \mathrm{N} / 83.3^{\circ} \mathrm{W}$ & (3300 m depth) & $\begin{array}{l}\text { Surrounded by Panama, } \\
\text { Colombia, Ecuador }\end{array}$ \\
\hline 13 & Coiba Ridge & $6.3^{\circ} \mathrm{N} / 81.45^{\circ} \mathrm{W}$ & $\begin{array}{c}150 \mathrm{~km} \\
(100 \mathrm{~km} \text { wide })\end{array}$ & Panama \\
\hline 14 & Cocos Ridge & $2.3-8.5^{\circ} \mathrm{N} / 82.8-90.3^{\circ} \mathrm{W}$ & $\begin{array}{c}1000 \\
(200 \mathrm{~km} \text { wide }) \\
(1000-3000 \mathrm{~m} \text { depth })\end{array}$ & $\begin{array}{l}\text { Cocos Plate, } \\
\text { Costa Rica }\end{array}$ \\
\hline 15 & Colon Ridge & $2^{\circ} \mathrm{N} / 96^{\circ} \mathrm{W}$ & & Undersea Features \\
\hline 16 & Guatemala Basin & $6-11^{\circ} \mathrm{N} / 87-99^{\circ} \mathrm{W}$ & (2600 m depth) & $\begin{array}{c}\text { Cocos Plate } \\
\text { (Guatemala, El Salvador, } \\
\text { Honduras, Nicaragua) }\end{array}$ \\
\hline 17 & Tehuantepec Ridge & $13.3^{\circ} \mathrm{N} / 98^{\circ} \mathrm{W}$ & (2000 - $4000 \mathrm{~m}$ depth) & West Coast Mexico \\
\hline 18 & East Pacific Rise & $\begin{array}{c}8.5-14^{\circ} \mathrm{N} / 104- \\
104.5^{\circ} \mathrm{W}\end{array}$ & (200 - 700 m depth) & $\begin{array}{c}\text { Gulf of California, } \\
\text { Pacific Plate/ } \\
\text { North American Plate/ } \\
\text { Cocos Plate }\end{array}$ \\
\hline
\end{tabular}


Table 2. East Pacific and Central American countries with precipitation, area, heat amount, volcano, earthquake and Ridge.

\begin{tabular}{|c|c|c|c|c|c|c|c|c|}
\hline \multirow[b]{2}{*}{ Country } & \multicolumn{2}{|c|}{ Precipitation } & \multirow[b]{2}{*}{$\begin{array}{l}\text { Area } \\
\left(\mathrm{km}^{2}\right)\end{array}$} & \multicolumn{2}{|c|}{ Heat Amount } & \multirow[b]{2}{*}{$\begin{array}{l}\text { Volcano } \\
\text { Number }\end{array}$} & \multirow[b]{2}{*}{$\begin{array}{c}\text { Earthquake } \\
\text { Number }\end{array}$} & \multirow[b]{2}{*}{ Ridge } \\
\hline & $\begin{array}{c}\text { During } \\
\text { year of } \\
2011(\mathrm{~mm})\end{array}$ & Rank & & $\begin{array}{c}\times 10^{18} \\
\mathrm{cal}\end{array}$ & Rank & & & \\
\hline Costa Rica & 2926 & 1 & 51,100 & 2.3 & 10 & 13 & 11 & $\begin{array}{l}\text { Cocos (Costa Rica } \\
\text { Province, Cocos } \\
\text { Island Province, } \\
\text { Southwest Province) }\end{array}$ \\
\hline Panama & 2692 & 2 & 74,177 & 3.0 & 9 & 3 & 4 & Coiba \\
\hline Colombia & 2612 & 3 & $1,141,748$ & 45 & 1 & 16 & 25 & $\begin{array}{c}\text { Carnegie/Malpelo/ } \\
\text { Columbia-Ecuador } \\
\text { Trench }\end{array}$ \\
\hline Nicaragua & 2391 & 4 & 129,494 & 4.7 & 6 & 19 & 9 & $\begin{array}{l}\text { Nicaraguan } \\
\text { fore-arc }\end{array}$ \\
\hline Ecuador & 2087 & 5 & 283,561 & 8.7 & 5 & 43 & 24 & Carnegie \\
\hline Guatemala & 1996 & 6 & 108,889 & 3.3 & 7 & 29 & 25 & $\begin{array}{c}\text { Middle American } \\
\text { Trench }\end{array}$ \\
\hline Honduras & 1976 & 7 & 112,492 & 3.3 & 8 & 4 & 3 & $\begin{array}{c}\text { Middle American } \\
\text { Trench }\end{array}$ \\
\hline Peru & 1738 & 8 & $1,279,999$ & 35 & 2 & 29 & 56 & Nazca \\
\hline El Salvador & 1724 & 9 & 21,040 & 0.5 & 11 & 22 & 16 & $\begin{array}{c}\text { Middle American } \\
\text { Trench }\end{array}$ \\
\hline Chile & 1522 & 10 & 756,102 & 18 & 4 & 137 & 133 & Chile Rise \\
\hline Mexico & 752 & 11 & $1,972,550$ & 23 & 3 & 42 & 64 & $\begin{array}{c}\text { Tehuantepec/ } \\
\text { East Pacific Rise }\end{array}$ \\
\hline
\end{tabular}

Panama (2692), Columbia (2612), Nicaragua (2391), Ecuador (2087) (Table 2). From the steam table [19], the difference in the specific volume of water evaporation, between a warm $30^{\circ} \mathrm{C}$ and cold $15^{\circ} \mathrm{C}$, is 61 $\mathrm{m}^{3} / \mathrm{kg}$, which is converted to the rainfall. During El Niño, California and the southern United States also tend to receive more rainfall. On the other hand, during past El Niño events, Indonesia, Central America and the southern and central Amazon experienced more fire activity than normal due to droughts [20], the latter being caused by lack of water evaporation forming the rainfall accounting for the total mass balance of water. Heat transport is mainly governed by the status of Humboldt, Panama, Cromwell, and South Equatorial Currents. Heat is delivered in numbered sequence from hot heat countries (Table 2) of Columbia (1), Peru (2), Mexico (3), Chile (4), and Ecuador (5) to the cold sinks of Nicaragua (6), Guatemala (7), Honduras (8), Panama (9), Costa Rica (10), and El Salvador (11) to produce high precipitations by collision between the cold Humbodt Current at $15^{\circ} \mathrm{C}$ and the warm Panama Current at $30^{\circ} \mathrm{C}$ to have a 
heat exchange of $Q=m C p(30-15)=15 \mathrm{~m}\left(\mathrm{cal} \cdot \mathrm{g}^{-1}\right)$. Heat amount $(Q)$ in calories was determined by multiplication of country area $\left(\mathrm{km}^{2}\right)$ with individual precipitations $(\mathrm{mm})$ to get the mass $(\mathrm{m})$ in gram assuming the water density of $1 \mathrm{~g} \cdot \mathrm{cm}^{-3}$ which is multiplied by 15 for the final determination of individual heat amount for each country, as shown in Table 2.

\subsection{Antarctic Currents, Seamounts, and Ridges}

Near the southern extremity of South America, most of the Antarctic Circumpolar Circulation (ACC) flows at $4 \mathrm{~km} \cdot \mathrm{h}^{-1}$ eastward into the Atlantic $\left(50^{\circ} \mathrm{S}\right)$, but part of it curves toward the left and flows generally northward along the west coast of South America as the Peru Current $\left(40^{\circ} \mathrm{S} 45^{\circ} \mathrm{S}\right)$. If the length of South American coastline $(8409 \mathrm{~km})$ is approximated, the time it takes the Peru Current from the Antarctic to reach the Galapagos, is determined at a minimal 2.9 months $\left\{=\frac{8409 \mathrm{~km}}{4} \mathrm{~km} \cdot \mathrm{h}^{-1}\right\}\left(24 \mathrm{~h} \cdot \mathrm{d}^{-1}\right)\left(30 \mathrm{~d} \cdot \mathrm{m}^{-1}\right)$ with a current speed of ACC $\left(4 \mathrm{~km} \cdot \mathrm{h}^{-1}\right)$. If applying the Peru Current speed of $40 \mathrm{~cm} \cdot \mathrm{s}^{-1}\left(1.44 \mathrm{~km} \cdot \mathrm{h}^{-1}\right)$ [21], the required time is 8.1 months $\left\{=(8409 \mathrm{~km}) / 1.44 \mathrm{~km} \cdot \mathrm{h}^{-1}\left(24 \mathrm{~h} \cdot \mathrm{d}^{-1}\right)\left(30 \mathrm{~d} \cdot \mathrm{m}^{-1}\right)\right\}$. Therefore, part of the ACC reaches the equatorial regime in the form of the Peru Current within a period of 2.9 months to 8.1 months.

During the El Niño, warm eastward-flowing waters from the equator dominate the Humboldt Current causing changes such as the increase of water temperature by up to $2^{\circ} \mathrm{C}$ to $3^{\circ} \mathrm{C}$, sea-level rises up to 40 to $50 \mathrm{~cm}$ and a reduction in the availability of surface nutrients. Such changes have devastating consequences for pelagic fisheries off Chile, Peru and Ecuador, and for the marine fauna that relies on these normally highly productive areas. The El Niño event has also been associated with coral bleaching, mortality and changes in the abundance and distribution of seabirds, marine mammals and sea turtles [22], which might be caused by volcanic activities of Ridge and Rises in Antarctica, as shown in Table 3.

Submarine volcanism occurs at the Mid Ocean Ridges (MORs), Back-Arc Spreading, Arc Volcanism, and Hotspots. The flux of volcanic $\mathrm{CO}_{2}$ to the ocean are MORs (27.8\%), Back-Arc Basins (37.8), Volcanic Arcs (34.1), Hotspots (0.3) [23]. The temperature of magma is $1200^{\circ} \mathrm{C}$ while cold seawater percolates down through the crust to produce black smokers at $350^{\circ} \mathrm{C}$ [17]. The California Current and Humboldt Current pass through oceanic hotspots with Holocene activity until they join together at the Galapagos Island Hotspots located at the boundaries of Cocos Plate and Nazca Plate [24].

\subsection{El Niño and La Niña Events}

Submarine volcanoes are underwater vents or fissures in the Earth's surface from which magma can erupt. They are estimated to account for $75 \%$ of annual magma output. The vast majority are located near areas of tectonic plate movement, known as ocean ridges. Many submarine volcanoes are seamounts, typically extinct volcanoes that rise abruptly from a seafloor of $1000-4000$ meters depth. The peaks are often found hundreds to thousands of meters below the surface, and are therefore considered to be within the deep sea. An estimated 30,000 seamounts occur across the globe [25].

El Nino/La Nina events can be classified as four typical cases depending upon the submarine volcanic activities at seamounts in Antarctica and South America, as summarized in Table 4.

Detailed description of columns in Table 4 are as follows:

1) Sunspot number in Figure 1 is categorized in 4 groups of strong maximal, weak maximal, weak minimal, and strong minimal. The strong maximal group is regarded as the period of the warmest SST due to submarine volcanic eruptions induced by the strong solar radiation. The strong minimal group is regarded as the period of the coldest SST due to lack of submarine volcanic eruptions induced by the weak solar radiation.

2) Submarine volcanic activities occur (o) or don't occur (x) at the seamounts of Antarctica (Table 3) and South America (Table 1) in conjunction with Rises and Ridges. 
Table 3. Antarctic seamounts and ridges.

\begin{tabular}{|c|c|c|c|c|}
\hline Step & Name & Location & Length (km) & Remark \\
\hline 1 & Pacific-Antarctic Ridge & $\begin{array}{l}54^{\circ} 30^{\prime}-65^{\circ} 28 \mathrm{~S} / \\
160^{\circ} 15^{\prime}-180^{\circ} \mathrm{E}\end{array}$ & & $\begin{array}{c}\text { Southern Extension of East Pacific } \\
\text { Rise (EPR) } \\
\text { (Pacific Plate/Antarctic Plate) }\end{array}$ \\
\hline 2 & Mid-Atlantic Rise & $15^{\circ} \mathrm{W}$ & & Atlantic Ocean \\
\hline 3 & Southwest Indian Ridge & $53^{\circ} \mathrm{S} / 20-24^{\circ} \mathrm{E}$ & $250 \mathrm{~km}$ & $\begin{array}{c}\text { Indian Ocean } \\
\text { (African Plate/Antarctic Plate) }\end{array}$ \\
\hline 4 & Southeast Indian Ridge & $\begin{array}{l}25-62^{\circ} \mathrm{S} / \\
70-170^{\circ} \mathrm{E}\end{array}$ & & $\begin{array}{c}\text { Indian Ocean seafloor } \\
\text { (Indo-Australian Plate/Antarctic } \\
\text { Plate) }\end{array}$ \\
\hline 5 & $\begin{array}{l}\text { S. Tasman Rise } \\
\text { (Tasmania Ridge) }\end{array}$ & $\begin{array}{l}45-51^{\circ} \mathrm{S} / \\
147-150^{\circ} \mathrm{E}\end{array}$ & $\begin{array}{c}(800-3000 \mathrm{~m} \\
\text { depth })\end{array}$ & Southern Ocean, Australia seafloor \\
\hline 6 & Campbell Plateau & $50^{\circ} 40^{\prime} \mathrm{S} / 171^{\circ} \mathrm{E}$ & $\begin{array}{l}(500-1000 \mathrm{~m} \\
\text { depth })\end{array}$ & $\begin{array}{c}\text { New Zealand } \\
\text { (Large submarine plateau) }\end{array}$ \\
\hline 7 & Chatham Rise & $\begin{array}{l}39^{\circ} 50^{\prime} \mathrm{S}-50^{\circ} 04^{\prime} \mathrm{S} / \\
171^{\circ} 29^{\prime}-178^{\circ} 03^{\prime}\end{array}$ & $\begin{array}{c}1000 \mathrm{~km} \\
(544-3735 \mathrm{~m} \\
\text { depth })\end{array}$ & $\begin{array}{c}\text { New Zealand } \\
\text { (Productive fishing ground) }\end{array}$ \\
\hline 8 & Marie Byrd Seamount & $\begin{array}{c}114-131^{\circ} \mathrm{W} / \\
68-71^{\circ} \mathrm{S}\end{array}$ & $800 \mathrm{~km}$ & Amundsen Sea \\
\hline 9 & Orca Seamount & $62^{\circ} \mathrm{S} / 58^{\circ} \mathrm{W}$ & $\begin{array}{c}3 \mathrm{~km} \text { wide } \\
\text { (500 m height) }\end{array}$ & Bransfield Strait \\
\hline 10 & $\begin{array}{l}\text { South Sandwitch Islands } \\
\text { (11 volcanic islands) }\end{array}$ & $\begin{array}{l}56^{\circ} 18^{\prime}-59^{\circ} 27^{\prime} \mathrm{S} / \\
26^{\circ} 23^{\prime}-28^{\circ} 08^{\prime} \mathrm{W}\end{array}$ & $\begin{array}{c}310 \mathrm{~km}^{2} \\
\text { (1370 m highest) }\end{array}$ & South Atlantic Ocean/Scotia Sea \\
\hline
\end{tabular}

Table 4. Four typical cases depending upon the submarine volcanic activities at seamounts in Antarctica and South America.

\begin{tabular}{|c|c|c|c|c|c|c|c|c|}
\hline Case & $\begin{array}{l}\text { Sunspot } \\
\text { Number }^{1)}\end{array}$ & $\begin{array}{c}\text { Submarine } \\
\text { Volcanic Activity }\end{array}$ & $\mathrm{SST}^{3)}$ & $\begin{array}{l}\text { Sea Ice } \\
\text { Extent }^{4)}\end{array}$ & $\begin{array}{c}\text { Krill } \\
\text { Abundance }^{5)}\end{array}$ & $\begin{array}{c}\text { Fishery } \\
\text { Productivity }^{6}\end{array}$ & $\begin{array}{c}\text { El } \\
\text { Niño }^{7)}\end{array}$ & $\begin{array}{l}\text { La Niña } \\
\text { 7) }\end{array}$ \\
\hline \multirow{2}{*}{ I } & Strong & Antarctica (o) & $\uparrow$ & $\downarrow$ & $\downarrow$ & $\downarrow$ & \multirow{2}{*}{$\uparrow \uparrow$} & \multirow{2}{*}{ - } \\
\hline & Maximal & South America (o) & $\uparrow \uparrow$ & - & - & $\downarrow \downarrow$ & & \\
\hline \multirow{2}{*}{ II } & Weak & Antarctica (x) & $\downarrow$ & $\uparrow$ & $\uparrow$ & $\uparrow$ & \multirow{2}{*}{$\uparrow$} & \multirow{2}{*}{ - } \\
\hline & Maximal & South America (o) & $\uparrow \downarrow$ & - & - & $\downarrow$ & & \\
\hline \multirow{2}{*}{ III } & Weak & Antarctica (o) & $\uparrow$ & $\downarrow$ & $\downarrow$ & $\downarrow$ & & \multirow[t]{2}{*}{$\downarrow$} \\
\hline & Minimal & South America (x) & $\downarrow \uparrow$ & - & - & $\uparrow$ & & \\
\hline \multirow{2}{*}{ IV } & Strong & Antarctica (x) & $\downarrow$ & $\uparrow$ & $\uparrow$ & $\uparrow$ & \multirow{2}{*}{-} & \multirow{2}{*}{$\downarrow \downarrow$} \\
\hline & Minimal & South America (x) & $\downarrow \downarrow$ & - & - & $\uparrow \uparrow$ & & \\
\hline
\end{tabular}


3) Sea surface temperature (SST) of the Equatorial Pacific is dependent upon SST caused by volcanic activities at seamounts in Antarctica (Table 3) and South America (Table 1) with Rises and Ridges. SST shows increase $(\uparrow)$, strong increase $(\uparrow \uparrow)$, decrease $(\downarrow)$, and strong decrease $(\downarrow \downarrow)$, strong or weak $(\uparrow \downarrow)$ or $(\downarrow \uparrow)$.

4) Sea ice extent is dependent upon undersea volcanoes found off the West Antarctic ice sheet of the South Georgia Islands and South Sandwich Island, whose undersea volcanic system generates earthquakes and releases heat into the ice above to destabilize parts of the ice cap [26]. Sea ice extent decreases $(\downarrow)$ with undersea volcanic eruption and increases $(\uparrow)$ without undersea volcanic eruption, and is only applicable to Antarctica.

5) Krill abundance is proportional to sea ice extent during austral winter. It decreases $(\downarrow)$ with volcanic eruptions while melting ice by volcanic heat is increased $(\uparrow)$ with weak volcanic eruption.

6) Fishery productivity is decreased $(\downarrow)$ or strongly decreased $(\downarrow \downarrow)$ if submarine volcanoes are present and have less phytoplankton growth due to volcanic toxic chemicals $\left(\mathrm{SO}_{2}, \mathrm{H}_{2} \mathrm{~S}, \mathrm{HCl}, \mathrm{HF}, \mathrm{H}_{2} \mathrm{SO}_{4}\right)$ and further kill fish, bird, turtles and coral reefs. With weak volcanic eruptions in Antarctica fishery productivity is increased $(\uparrow)$ or further strongly increased $(\uparrow \uparrow)$ with weak eruptions at seamounts of South America.

7) El Niño is strong $(\uparrow \uparrow)$ when there are eruptions at the seamounts of Antarctica and South America at the same time, as in Case I. El Niño is weak $(\uparrow)$ if the seamounts of South America have eruptions while no eruptions in the Antarctica, as in Case II. La Niña is weak $(\downarrow)$ due to cooling by the Peru Current if there is only volcanic eruption in the undersea Antarctica with no volcanic eruptions at the seamounts of South America, as in Case III. There is a strong $(\downarrow \downarrow)$ La Niña if neither Antarctica nor South America have any submarine volcanic activities, as in Case IV.

It is important to note that the extents of El Niño or La Nina events are dependent upon the submarine volcanic activities in Antarctica and South America. It can be thus postulated that El Nino and La Nina events are induced by the various degree of volcanic eruptions of seamounts in Antarctica, Central America, South America, and GHS, whose thermal currents toward the east Pacific and the west Pacific can be schematically drawn in Figure 3.

There are two major currents induced by centrifugal forces of ACC to be perpendicular to two exits: one is East Australian Current (EAC) between Tasmania of Australia and New Zealand while another is

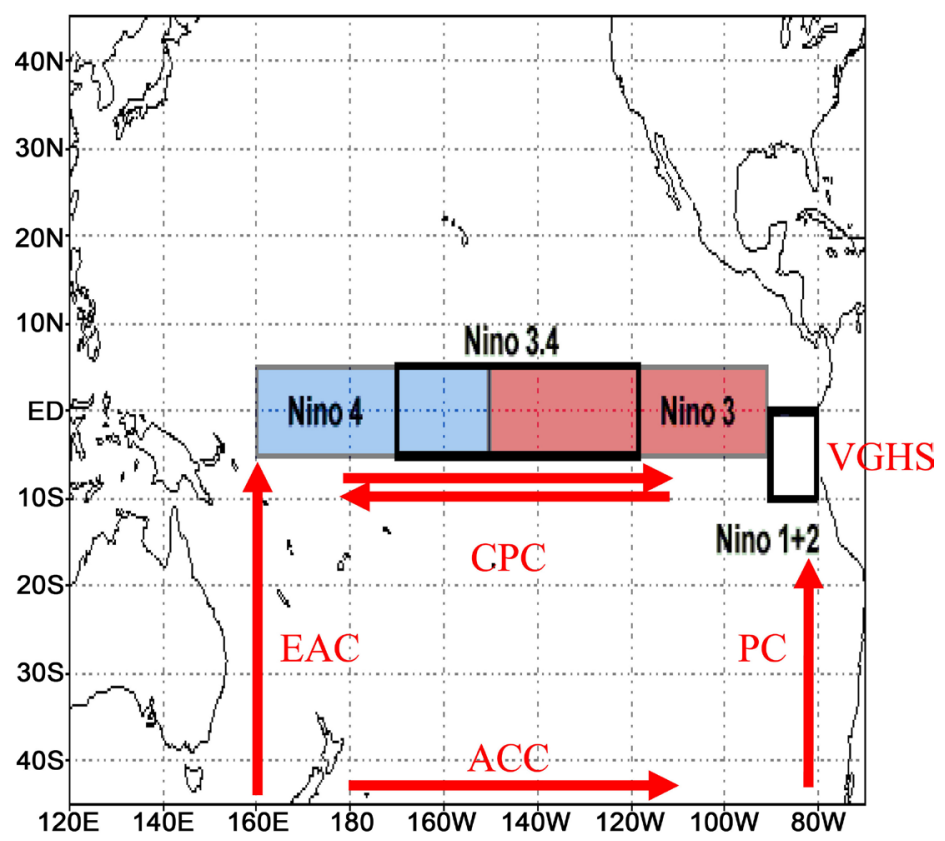

Figure 3. Currents with volcanic seamounts in Antarctica, Central America, South America, and Galapagos Hot Spots. 
the Peru Current (PC) along the west coast of South America. The shortest course to reach the central Pacific ocean around the equator is EAC while the slowest course is PC. It appears that the Volcanic activity in the GHS (VGHS) is the key parameter to control the direction of Ocean Surface Current of Central Pacific Current (CPC). If SST of VGHS plus PC is warmer, due to the strong volcanic eruptions in the Seamounts and the Ridges in South and Central Americas (Table 1) than SST of EAC, CPC flows from east to west due to the second law of thermodynamics for thermal flow from hot source to cold sink. In contrast the opposite direction is made if SST in EAC is warmer, due to the strong volcanic eruptions in the Antarctic Seamounts and Ridges (Table 3), than SST of the sum of VGHS and PC (Table 1).

\subsection{El Niño Index and La Niña Index with Sunspot Number}

When $\mathrm{CO}_{2}$ is increased, ozone $\left(\mathrm{O}_{3}\right)$ layers in the Poles become thinner so that UV radiation [5] upon the Earth is increased. Increased solar radiation during maximal sunspot number [6] and enhanced $\mathrm{CO}_{2}$ emission may induce El Niño events through warm SST and strong volcanic eruptions at seamounts in Antarctica, South America, and GHS.

The El Niño Index was plotted in Figure 4(a) with respect to sunspot numbers in Figure 1 at each El

(a)

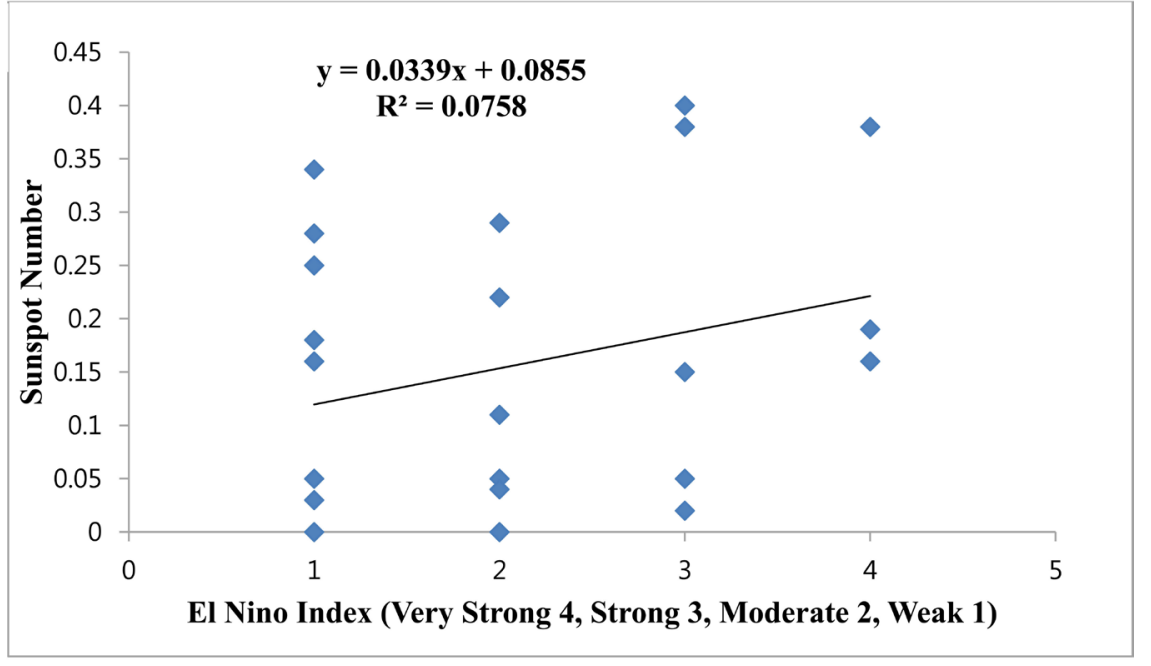

(b)

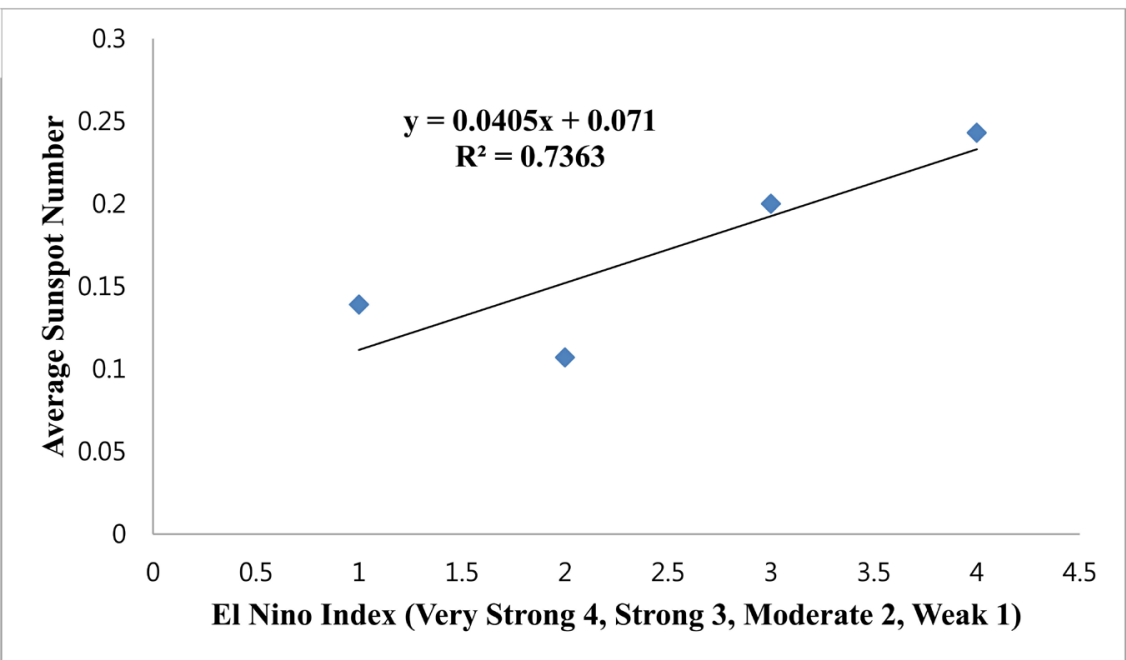

Figure 4. (a) El Niño Index of positive correlation with 4 intensities (very strong, strong, moderate, weak) of El Niño events in Table 5 with respect to the corresponding sunspot number in Figure 1. (b) El Niño Index of positive correlation with average sunspot number at each degree of El Niño event in Table 5. 
Niño Index, defined as 4 degrees (Very Strong 4, Strong 3, Moderate 2, Weak 1) of intensity from data in Table 5 while Figure 4(b) $\left(R^{2}=0.7363\right)$ was positively plotted with respect to average sunspot number. Due to the industrial development, $\mathrm{CO}_{2}$ emission is continuously increasing. At minimal sunspot number in Figure 1, there is a weak solar radiation to induce cold SST and weak volcanic eruptions at seamounts for La Niña. La Niña Index, defined as 3 degrees (Strong 3, Moderate 2, Weak 1) from data in Table 5 was negatively plotted in Figure 5(a) with respect to sunspot number. The sunspot number at each degree of La Niña Index was averaged to get Figure $5(\mathrm{~b})$ with significant linearity $\left(R^{2}=0.9922\right)$. It is interesting to note that very strong El Niño events occur frequently during the maximal sunspot in Table 5 while strong La Niña events happen more often during the minimal sunspot number in Table 5.

\subsection{El Niño Event with Volcanic Eruption in Galapagos Hot Spot}

The year of volcanic eruption in the GHS [27] was correlated with the year of El Niño events in Table 5 to get the significant linearity $\left(R^{2}=0.9939\right)$ in Figure 6. It is evident that an El Niño event is significantly dependent upon the volcanic eruption in the GHS. During the El Niño years of 1986, 1997, 2003, 2006, and 2014 in Table 5, there were no volcanic eruptions in the aboveground of the GHS [27]. However, a

(a)

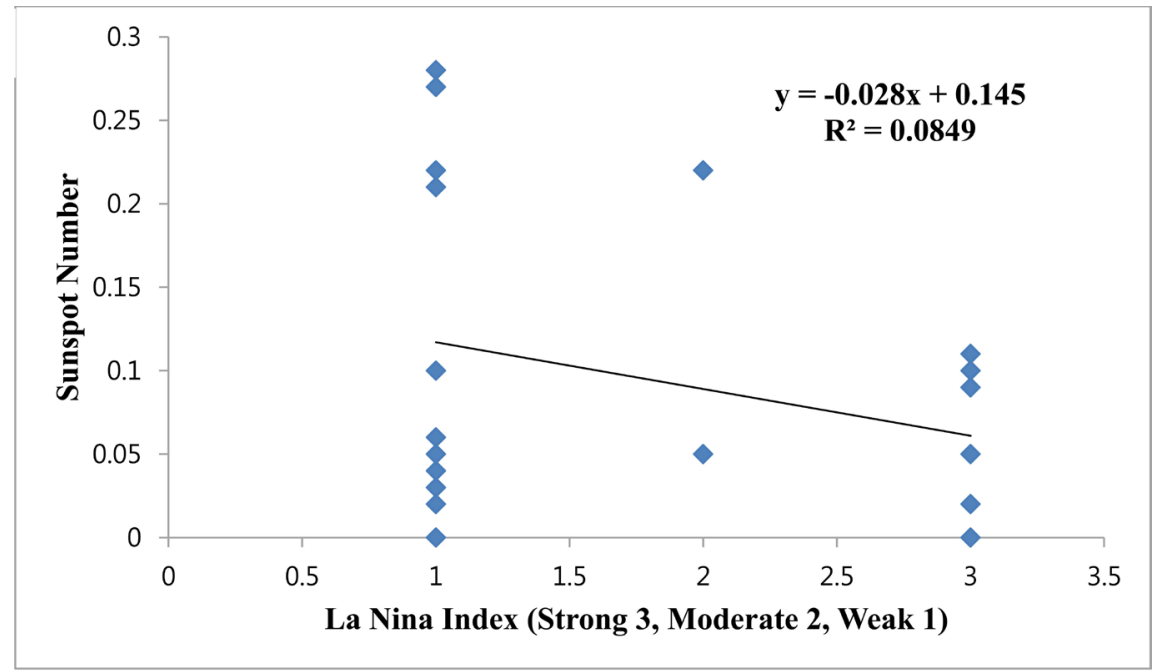

(b)

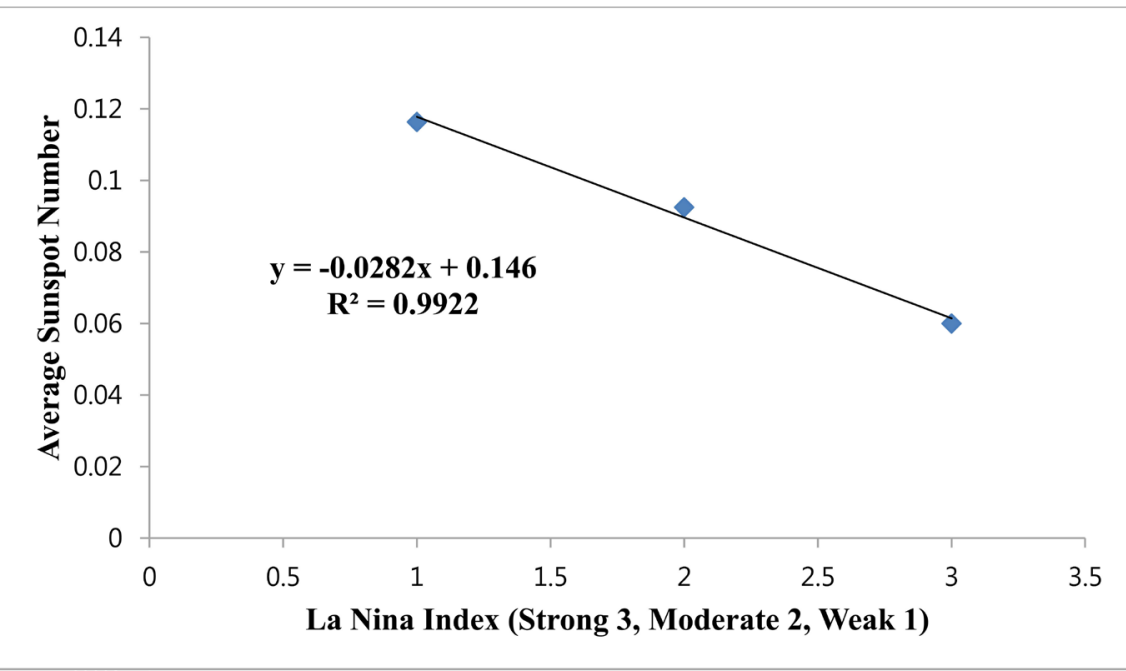

Figure 5. (a) La Niña Index of negative correlation with 3 degrees of intensity (strong, moderate, weak) in Table 5 with respect to the corresponding sunspot number in Figure 1. (b) La Niña Index of negative correlation with average sunspot number at each degree of La Niña event in Table 5. 
Table 5. El Niño and La Niña years with the sunspot number in Figure 1 and their intensities based on Oceanic Niño Index (ONI) [12] while $4 \mathrm{El} \mathrm{Niño} \mathrm{Index} \mathrm{(very} \mathrm{strong} \mathrm{4,} \mathrm{strong} \mathrm{3,} \mathrm{moderate} \mathrm{2,} \mathrm{weak}$ 1) and $3 \mathrm{La}$ Niña Index (strong 3, moderate 2, weak 1) give the sunspot numbers in parenthesis at each intensity of El Niño/La Niña events. It appears that very strong El Niño events occur frequently during the maximal sunspot number while strong La Niña events occur more often during the minimal sunspot number.

\begin{tabular}{ccccccc}
\hline \multicolumn{3}{c}{ El Niño (Sunspot Number) } & \multicolumn{3}{c}{ La Niña (Sunspot Number) } \\
\hline \multicolumn{3}{c}{ (El Niño Index) } & \multicolumn{3}{c}{ (La Niña Index) } \\
\hline Weak (1) & Moderate (2) & Strong (3) & Very Strong (4) & Weak (1) & Moderate (2) & Strong (3) \\
\hline $1952-53(0.05)$ & $1951-52(0.05)$ & $1957-58(0.4)$ & $1982-83(0.38)$ & $1954-55(0)$ & $1955-56(0.05)$ & $1973-74(0.09)$ \\
$1953-54(0.05)$ & $1963-64(0.04)$ & $1965-66(0.02)$ & $1997-98(0.16)$ & $1964-65(0.06)$ & $1970-71(0.22)$ & $1975-76(0)$ \\
$1958-59(0.34)$ & $1968-69(0.22)$ & $1972-73(0.15)$ & $2015-16(0.19)$ & $1971-72(0.21)$ & $1995-96(0.05)$ & $1988-89(0.05)$ \\
$1969-70(0.16)$ & $1986-87(0.04)$ & $1987-88(0.05)$ & & $1974-75(0.03)$ & $2011-12(0.05)$ & $1998-99(0.1)$ \\
$1976-77(0)$ & $1994-95(0.11)$ & $1991-92(0.38)$ & & $1983-84(0.28)$ & $1999-00(0.11)$ \\
$1977-78(0.03)$ & $2002-03(0.29)$ & & & $1984-85(0.22)$ & $2007-08(0.05)$ \\
$1979-80(0.25)$ & $2009-10(0)$ & & $2000-01(0.27)$ & $2010-11(0.02)$ \\
$2004-05(0.28)$ & & & $2005-06(0.1)$ & \\
$2006-07(0.05)$ & & & $2008-09(0.02)$ & \\
$2014-15(0.18)$ & & & & $2016-17(0.04)$ & \\
& & & $2017-18(0.05)$ & \\
\end{tabular}

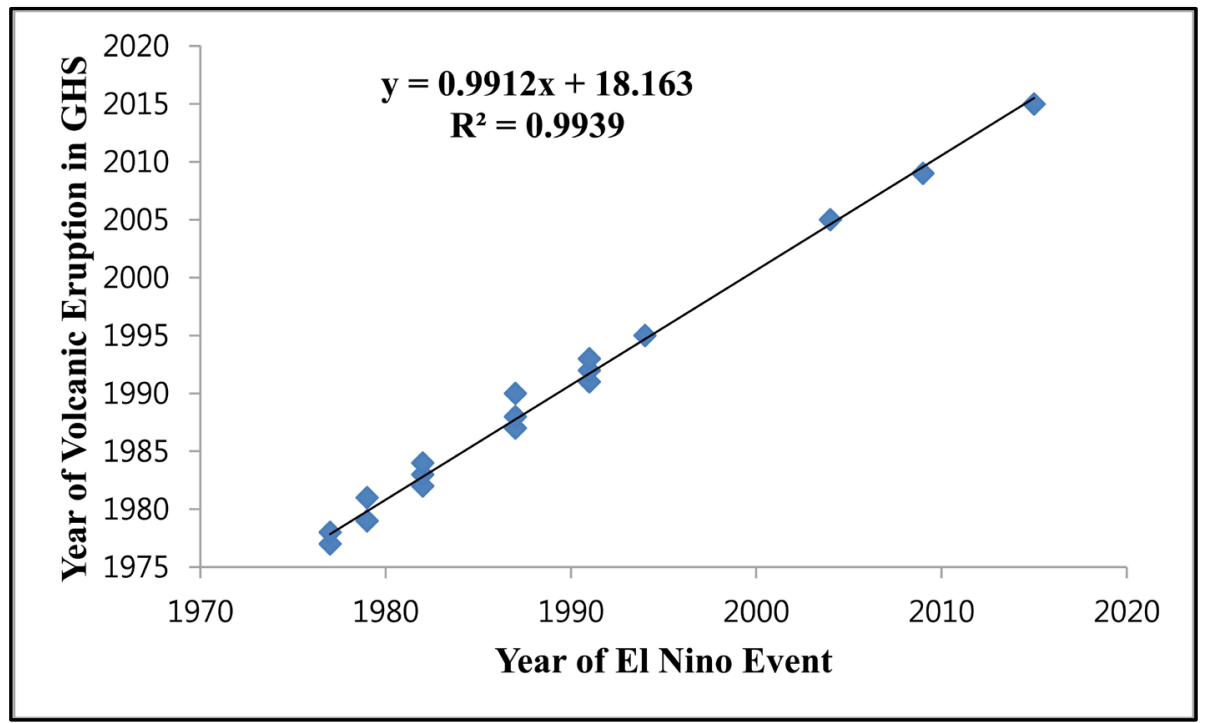

Figure 6. Year of volcanic eruption (y) in the Galapagos Hot Spot [27] versus the year of El Niño event $(x)$ in Table 5 from years of 1977 to 2016.

Galapagos expedition by an international team led by the Woods Hole Oceanographic Institution (WHOI) revealed 70 unknown seamounts [28]. Warm SST during El Niño event may activate the thermal energy in 
the submarine seamount for volcanic eruption. Therefore, some of 70 seamounts in the GHS could volcanically erupt to induce El Niño events during such vacant years. It may be possible to predict the year of the El Niño event if there are volcanic eruptions either from aboveground volcanoes or submarine seamounts in the GHS.

\subsection{Greenhouse-Gas Induction of El Niño}

During the maximal sunspot number, there is an El Niño event, as shown in Figure 5(b). As greenhouse-gas increases, the ozone hole deteriorates to induce El Niño, as shown in Figure 7. Since greenhouse-gas continuously increases, it is therefore proposed that the maximal sunspot number is a major parameter for prediction of El Niño while the minimal sunspot number works in the same way for La Niña, as schematically summarized in Figure 7.

\subsection{Record Low Temperatures in Chicago with Minimal Sunspot Number}

"Life-threatening" temperatures hit record daily low in Chicago [29]; Temperature fell to make it the coldest Jan. 30, 2019 in Chicago on record minus 19 degrees, which beats the last record of minus 15 on Jan. 30, 1966. The lowest recorded temperature in Chicago ever is minus 27 degrees in 1985 [30]. The 3 years of 1966, 1985, and 2019 are expressed in green arrows in Figure 1 of the sunspot number. Figure 8 implies that the year of the lowest record temperatures in Chicago in Table 6 from 1873 to 2019 [30] is significantly $\left(R^{2}=0.9995\right)$ proportional to the year of the minimal sunspot number. Therefore, the lowest

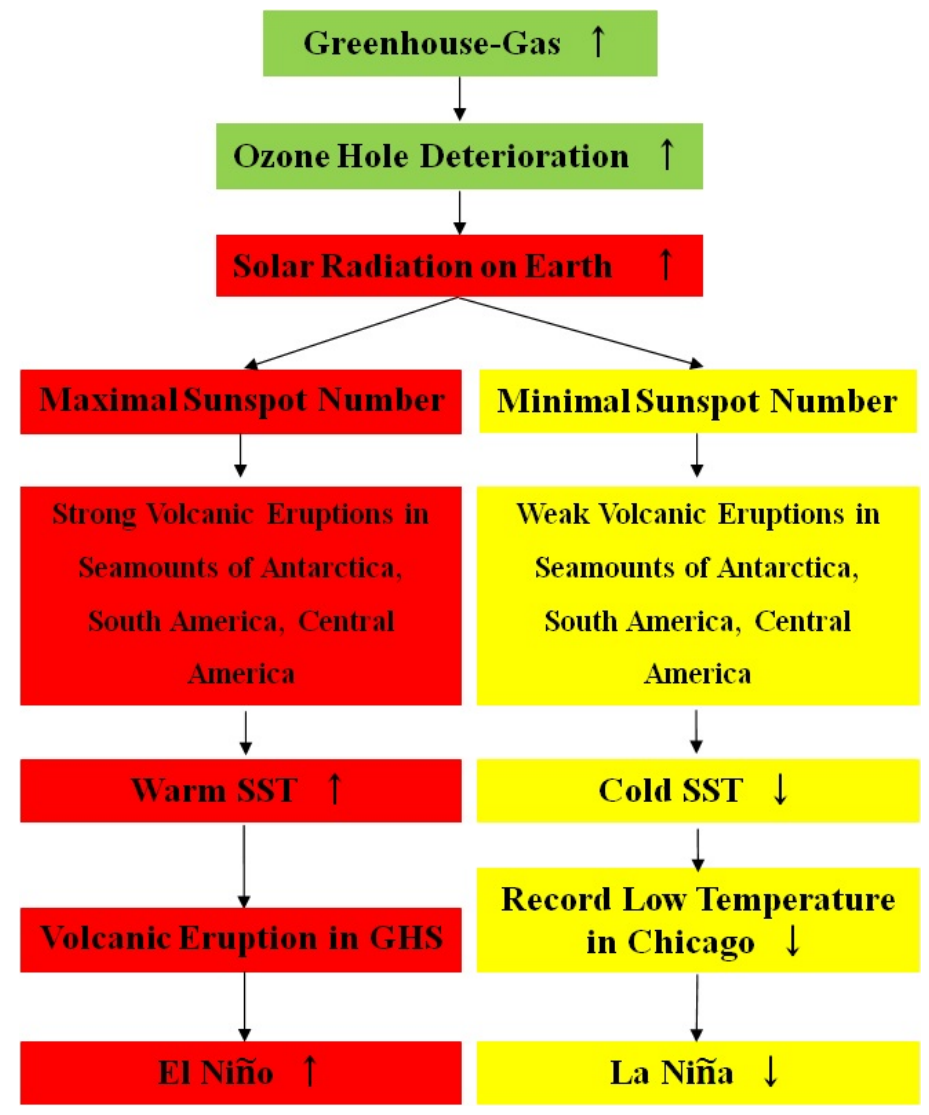

Figure 7. Schematic flow diagram of greenhouse-gas to induce a El Niño event with the maximal sunspot number associated with very strong volcanic eruptions in seamounts of Antarctica, South America, Central America, GHS while a La Niña event with the minimal sunspot number associated with the weak volcanic eruption and the record low temperature in Chicago. 


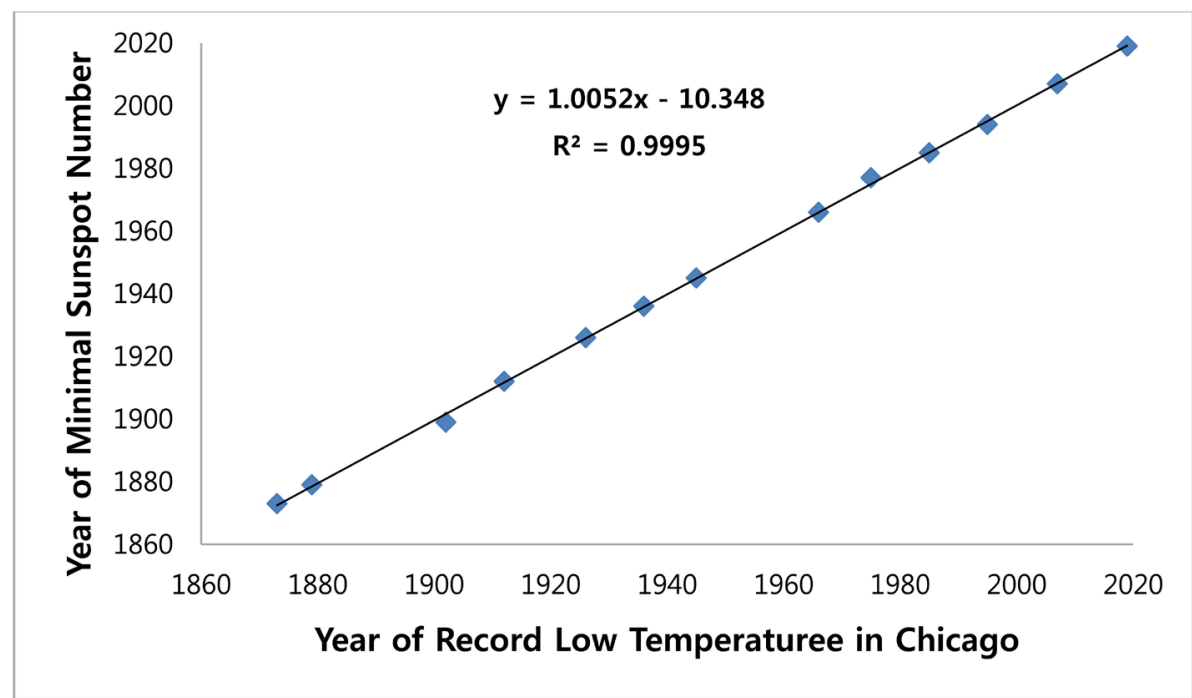

Figure 8. The record low temperatures in Chicago in relation to the years of minimal sunspot number in Table 6.

Table 6. Years showing the record low temperature in Chicago with the years of minimal sunspot number from 1873 to 2019 and the years of corresponding La Niña events.

\begin{tabular}{ccc}
\hline $\begin{array}{c}\text { Year of Record Low Temperature } \\
\text { in Chicago [30] }\end{array}$ & $\begin{array}{c}\text { Year of Minimal } \\
\text { Sunspot Number (Figure 1) }\end{array}$ & $\begin{array}{c}\text { Year of Corresponding } \\
\text { La Niña Event (Table 5) }\end{array}$ \\
\hline February 23, 1873 & 1873 & - \\
January 2, 1879 & 1879 & - \\
February 8, 1899 & 1902 & - \\
January 7, 1912 & 1912 & - \\
1926 & 1926 & - \\
January 22, 1936 & 1936 & - \\
1945 & 1945 & $1964-65$ \\
January 29, 1966 & 1966 & $1974-75$ \\
January 16, 1977 & 1975 & $1984-85$ \\
January 20, 1985 & 1985 & $1995-96$ \\
January 19, 1994 & 1995 & $2007-08$ \\
February 5, 2007 & 2007 & $2017-18$ \\
January 30, 2019 & 2019 & - \\
\hline
\end{tabular}

record temperatures can be predicted during the year of minimum sunspot number along with the corresponding La Niña events in Table 6.

Furthermore, it can be predicted that record low temperatures in Chicago can occur during La Niña event, both of which showed good proportionalities; La Niña Index, $R^{2}=0.9922$ in Figure 5(b), and the record low temperature in Chicago, $R^{2}=0.9995$ in Figure 6 with the year of minimal sunspot number, respectively. 
It may be possible to predict very strong El Niño events with the year of maximal sunspot number as El Niño Index $\left(R^{2}=0.7363\right)$ and the years of strong volcanic eruption in the Galapagos Hot Spot (GHS) $\left(R^{2}=0.9939\right)$, respectively. An El Niño event is thus expected during the year of strong volcanic eruption in the GHS. Strong La Niña events can be expected during the year of minimal sunspot number with La Niña Index $\left(R^{2}=0.9922\right)$. Record low temperatures in Chicago can be also predicted $\left(R^{2}=0.9995\right)$ during the year of the minimal sunspot number, as was recently the case in January, 2019.

\section{CONCLUSIONS}

The El Niño Index, defined as 4 intensities (very strong, strong, moderate, weak) in Oceanic Niño Index (ONI), was positively correlated with the average sunspot number at each intensity. The La Niña Index, defined as 3 intensities (strong, moderate, weak) in ONI, was negatively correlated with the average sunspot number from 1954 to 2017.

It appears that very strong El Niño events occur frequently during the maximal sunspot number while strong La Niña events occur more often during the minimal sunspot number. Since greenhouse-gas continuously increases, it is therefore proposed that the maximal sunspot number is a major parameter for prediction of El Niño while the minimal sunspot number serves a predictive role for La Niña.

There can be four typical cases depending upon the submarine volcanic activities at seamounts in Antarctica and South America for the various degrees of El Nino/La Nina events. If Sea Surface Temperature (SST) of South and Central Americas is warmer, due to the strong volcanic eruptions in the Seamounts and the Ridges in South and Central Americas than SST of East Australian Current (EAC), Central Pacific Current (CPC) flows from east to west due to the second law of thermodynamics for thermal flow from hot source to cold sink. In contrast the opposite direction is made if SST in EAC is warmer, due to the strong volcanic eruptions in the Antarctic Seamounts and Ridges, than SST in the Central/South American Seamounts and Ridges.

The years of the record low temperatures in Chicago from 1873 to 2019 were significantly correlated with the years of the minimal sunspot number.

It is forecast that a weak La Niña may occur in 2019 and another record low temperature in Chicago in January of 2020 due to the phase of the minimal sunspot number in 2019.

It may be possible to predict very strong El Niño events with the year of maximal sunspot number as El Niño Index $\left(R^{2}=0.7363\right)$ and the years of strong volcanic eruption in the Galapagos Hot Spot (GHS) $\left(R^{2}=0.9939\right)$, respectively. An El Niño event is thus expected during the year of strong volcanic eruption in the GHS. Strong La Niña events can be expected during the year of minimal sunspot number with La Niña Index $\left(R^{2}=0.9922\right)$. Record low temperatures in Chicago can be also predicted $\left(R^{2}=0.9995\right)$ during the year of the minimal sunspot number, as was recently the case in January, 2019.

\section{ACKNOWLEDGEMENTS}

The author expresses sincere gratitude to the University of Suwon and G-Land of South Korea for their financial supports. Editing work undertaken by Professor Jonathan Wright is also greatly appreciated.

\section{CONFLICTS OF INTEREST}

The author declares no conflicts of interest regarding the publication of this paper.

\section{REFERENCES}

1. Hathaway, D.H. (2010) The Solar Cycle. Living Reviews in Solar Physics, 7, 1.

https://doi.org/10.12942/lrsp-2010-1

2. Hathaway, D.H. (2015) The Solar Cycle. Living Reviews in Solar Physics, 12, 4.

https://doi.org/10.1007/lrsp-2015-4 
3. https://www.weather.gov/fsd/sunspots

4. Kim, T.J., Prev Philander, S.G. and Fedorov, A. (2003) Is El Niño Sporadic or Cyclic? Annual Review of Earth and Planetary Sciences, 31, 579-594. https://doi.org/10.1146/annurev.earth.31.100901.141255

5. Kim, T.-J. (2018) Prevention of Avian Influenza Virus by Ultraviolet Radiation and Prediction of Outbreak by Satellite Parameters. Journal of Biomedical Science and Engineering, 11, 182-206. https://doi.org/10.4236/jbise.2018.117015

6. Kim, T.J. (2019) Spanish Flu, SARS, MERS-CoV by $\mathrm{CO}_{2}$ Emission and Maximal Sunspot Number. Journal of Biomedical Science and Engineering, 12, 53-75. https://doi.org/10.4236/jbise.2019.121005

7. NASA TV (2015) El Niño Event as Never before. https://www.nasa.gov/feature/goddard/nasa-studying-2015-el-nino-event-as-never-before

8. Jet Propulsion Laboratory (2016) El Niño/La Niña Observations. https://climatesciences.jpl.nasa.gov/projects/enso

9. Hille, K. (2015) NASA Maps El Niño's Shift on U.S. Precipitation. NASA.

10. Mancero, J. (2017) Climate Change and Galapagos. Galapagos Island.com.

11. Atkins, P. and Paula, J. (2010) Physical Chemistry. 9th Edition, W. H. Freeman Co., New York.

12. Null, J. (2019) Historic Oceanic Niño Index (ONI) \& La Niña Winter Impacts on United States Weather Patterns. Golden Gate Weather Patterns. https://www.ggweather.com/enso/oni_la_nina.htm

13. NOAA (2019) Equatorial Pacific Sea Surface Temperatures. https://www.ncdc.noaa.gov/teleconnections/enso/indicators/sst

14. MacDonald, K. (2010) What Is a Hotspot. NOAA Ocean Explorer. https://oceanexplorer.noaa.gov>hotspots

15. Pedoja, K., et al. (2006) Plio-Quarternary Uplift of the Manta Peninsula and La Plata Island and the Subduction of the Carnegie Ridge, Central Coast of Ecuador. Journal of South American Earth Sciences, 22, 1-21. https://doi.org/10.1016/j.jsames.2006.08.003

16. Glynn, P.W. (1988) El Niño-Southern Oscillation 1982-1983: Nearshore Population, Community, and Ecosystem Responses. Annual Review of Ecology and Systematics, 19, 309-346.

https://doi.org/10.1146/annurev.es.19.110188.001521

17. Fornari, D., et al. (2004) Submarine Lava Flow Emplacement at the East Pacific Rise $9^{\circ} 50^{\prime} \mathrm{N}$ : Implications for Uppermost Ocean Crust Stratigraphy and Hydrothermal Fluid Circulation. Geophysical Monography, 148, 187-218. https://doi.org/10.1029/148GM08

18. (2011) United States Geological Survey Volcano Hazards Program. 22.

19. Balzhiser, R.E., Samuels, M.R. and Eliassen, J.D. (1972) Chemical Engineering Thermodynamics: The Study of Energy, Entropy, and Equilibrium. Prentice-Hall, Inc., Hoboken.

20. Perkins, L. (2004) AURA/OMI Tropospheric Ozone on a Flat Map. Scientific Visualization Studio. https://svs.gsfc.nasa.gov/cgi-bin/details.cgi?aid=3071

21. Penven, P., et al. (2005) Average Circulation, Seasonal Cycle, and Mesoscale Dynamics of the Peru Current System: A Modeling Approach. Journal of Geophysical Research, 110, 67-87. https://doi.org/10.1029/2005JC002945

22. Cucalom, E. (1987) Oceanographic Variability off Ecuador Associated with an El Nino Event in 1982-1983. Journal of Geophysical Research, 92, 14309-14322. https://doi.org/10.1029/JC092iC13p14309

23. IEA (2009) Greenhouse Gas R \& D Programme Assessment of Sub Sea Ecosystem Impacts. Technical Study Report No. 2008/8, IEA Environmental Projects Ltd.

24. Global CCS Institute (2015) 2.2 Natural Flux of Volcanic $\mathrm{CO}_{2}$ to Ocean Bottom Waters.

25. Mitchell, N.C. (2003) Susceptibility of Mid-Ocean Ridge Volcanic Islands and Seamounts to Large-Scale 
Landsliding. Journal of Geophysical Research, 108, 2397. https://doi.org/10.1029/2002JB001997

26. Wadhams, P. (2016) The Global Impacts of Rapidly Disappearing Arctic Sea Ice. YaleEnvironmet360. https://e360.yale.edu/features/as_arctic_ocean_ice_disappears_global_climate_impacts_intensify_wadhams

27. Kim, T.J. (2018) Mitigation of Ecuadorian Earthquake Impact. Open Journal of Earthquake Research, 7, 195-219. https://doi.org/10.4236/ojer.2018.73012

28. New Species (2015) Woods Hole Oceanographic Galapagos Expedition Reveals Unknown Seamounts.

29. Struett, D. (2019) "Life-Threatening" Temperatures Hit Record Daily Low in Chicago. Chicago Sun Times. https://chicago.suntimes.com/news/chicago-breaks-daily-record-low-temperature-weather-service

30. National Oceanic and Atmospheric Administration (2019) Temperature Records, National Weather Service. Chicago. 